\title{
KONTRIBUSI KONSEP DIRI DAN PERHATIAN ORANG TUA TERHADAP HASIL BELAJAR MATEMATIKA SISWA KELAS X SMA DI KECAMATAN WERA BIMA
}

\author{
Dusalan* \\ Program Studi Pendidikan Matematika, STKIP Bima \\ *Email korespondensi: dusalanbima84@gmail.com
}

\begin{abstract}
ABSTRAK
Tujuan penelitian ini adalah (1) Ingin mengetahui seberapa besar kontribusi konsep diri, dan Perhatian orang tua, terhadap hasil belajar matematika siswa kelas X SMA di Kecamatan Wera Bima; (2) Ingin mengetahui seberapa besar kontribusi positif konsep diri terhadap hasil belajar matematika siswa kelas X SMA di Kecamatan Wera Bima; dan (3) Ingin mengetahui seberapa besar kontribusi positif perhatian orang tua terhadap hasil belajar matematika siswa kelas X SMA di Kecamatan Wera Bima. Jenis penelitian ini adalah ex-post facto, Populasi dalam penelitian ini adalah siswa Kelas X SMA Negeri di Kecamatan Wera Bima tahun pelajaran 2017/2018 yang diambil dengan menggunakan Proporsional stratified random sampling. Instrumen yang digunakan: (1) skala konsep diri, (2) skala perhatian orang tua, (3) tes hasil belajar matematika. Data dianalisis dengan statistik deskriptif dan analisis jalur. Hasil penelitian memberikan gambaran bahwa; (1) Kontribusi positif konsep diri, dan Perhatian orang tua secara bersama-sama (simultan) terhadap hasil belajar matematika siswa kelas X SMA di Kecamatan Wera Bima, sebesar $\mathrm{R}_{\text {square }}^{2}=11,10 \%$. (2) Kontribusi positif konsep diri terhadap hasil belajar matematika siswa kelas X SMA di Kecamatan Wera Bima, sebesar 15,70\%. dan (3) Kontribusi positif perhatian orang tua terhadap hasil belajar matematika siswa kelas X SMA di Kecamatan Wera Bima, sebesar 19,80\%.
\end{abstract}

Kata kunci: konsep diri, perhatian orang tua, hasil belajar matematika

\begin{abstract}
The purpose of this study is (1) Want to know how much the contribution of self-concept, and the attention of parents, to the results of mathematics learning in class X SMA in Wera Bima District; (2) Want to know how much the positive contribution of self-concept to the results of mathematics learning in class X SMA in Wera Bima District; and (3) Want to know how much the positive contribution of parents' attention to the results of mathematics learning in class X SMA in Wera Bima District. The type of this study was ex-post facto, the population in this study were Class X students of State High Schools in Wera Bima Subdistrict in the year 2017/2018 which were taken using Proportional stratified random sampling. Instruments used: (1) self-concept scale, (2) the scale of parental attention, (3) tests of mathematics learning outcomes. Data were analyzed by descriptive statistics and path analysis. The results of the study illustrate that; (1) Positive contribution to selfconcept, and parents' attention together (simultaneous) to the mathematics learning outcomes of class $\mathrm{X}$ high school students in Wera Bima District, for $\mathrm{R}_{\text {square }}^{2}=11.10 \%$. (2) The positive contribution of self-concept towards the mathematics learning outcomes of class X high school students in Wera Bima Subdistrict, amounting to $15.70 \%$. and (3) The positive contribution of parents' attention
\end{abstract}


to the mathematics learning outcomes of class $\mathrm{X}$ high school students in Wera Bima District, amounting to $19.80 \%$

Keywords: self-concept, parental attention, mathematics learning outcomes

\section{PENDAHULUAN}

Undang-Undang Nomor 20 Tahun 2003 tentang sistem pendidikan nasional menyatakan bahwa pendidikan adalah usaha sadar dan terencana untuk mewujudkan suasana belajar dan proses pembelajaran agar peserta didik secara aktif mengembangkan potensi dirinya untuk memiliki kekuatan spiritual keagamaan, pengendalian diri, kepribadian, kecerdasan, akhlak mulia, serta keterampilan yang diperlukan dirinya, masyarakat, bangsa dan Negara.

Djaali (2012) mengemukakan bahwa faktor-faktor yang mempengaruhi pencapaian hasil belajar siswa yaitu berasal dalam diri seseorang atau faktor internal (misalnya konsep diri) dan ada dari luar diri seseorang atau faktor eksternal (misalnya lingkungan keluarga (bimbingan, dukungan dan perhatian orang tua serta motivasi belajar siswa), lingkungan sekolah, lingkungan pergaulan) dari anak didik, sehingga dapat membentuk karakter yang lebih mampu merespon positif setiap perubahan.

Berdasarkan hasil wawancara tidak terstruktur dengan guru dan siswa pada beberapa sekolah yang akan menjadi tempat penelitian, menunjukkan bahwa siswa tidak menyadari sepenuhnya fungsi keberadaan dirinya (konsep diri) di sekolah, sehingga menganggap sekolah hanya ritual pagi-sore, serta siswa menganggap perhatian orang tua siswa sangat kurang. Hal ini diperparah jika siswa yang memasuki usia sekolah bukan keinginan pribadi melainkan atas dorongan orang lain. Hal ini menjadi fokus perhatian peneliti untuk mengungkapkan sejauh mana kontribusi atau peran dari konsep diri dan perhatian orang tua terhadap hasil belajar. Peneliti menyadari betapa pentingnya konsep diri, dan perhatian orang tua untuk dikembangkan dalam pembelajaran sehingga hasil belajar yang diharapkan dapat tercapai sesuai yang diharapkan.

Konsep diri jika ditinjau dari beberapa literatur yang ada merupakan bagian penting dalam perkembangan kepribadian. Seperti yang dikemukakan oleh Rogers (dalam Thalib, 2010:121) bahwa konsep kepribadian yang paling utama adalah diri. Diri (Self) berisi ide-ide, persepsi-persepsi dan nilai-nilai yang mencakup kesadaran tentang diri sendiri. Konsep diri merupakan representasi diri yang mencakup identitas diri yakni karakteristik personal, pengalaman, peran dan status sosial. Hal ini kemudian kepribadian seseorang bisa diketahui melalui pendekatan emosional atau melakukan tes yang menyangkut konsep diri siswa. 
Menurut Hamachek (dalam Dusalan, 2013), konsep diri dalam literatur psikologis diuraikan sebagai suatu pandangan keseluruhan pada diri yang dimiliki oleh seorang individu.

Selain konsep diri, perhatian juga menjadi bagian yang penting dalam pengembangan kepribadian. Perhatian merupakan pemusatan atau konsentrasi dari seluruh aktivitas individu yang ditujukan kepada sesuatu atau sekumpulan obyek (Tisnadi, 2009). Selanjutnya menurut Slameto (2010: 107) bahwa perhatian adalah kegiatan yang dilakukan seseorang dalam hubungannya dengan pemilihan rangsangan yang datang dari lingkungan. Menurut Suharman (2005) bahwa perhatian (attention) adalah proses kosentrasi pikiran atau pemusatan aktivitas mental (attention is a concentration of mental activity). Lebih lanjut dikatakan bahwa proses perhatian melibatkan pemusatan pikiran pada tugas tertentu, sambil berusaha mengabaikan stimulus lain yang mengganggu, misalnya ketika seseorang sedang mengikuti ujian. Dari beberapa pendapat tersebut dapat ditarik benang merah bahwa perhatian adalah kegiatan yang dilakukan seseorang dalam hubungannya dengan pemilihan rangsangan yang datang dari lingkungan yang nanti berimbas pada hasil belajar.

Berdasarkan kajian di atas, menurut beberapa penelitian membuktikan bahwa konsep diri, motivasi berprestasi dan perhatian orang tua mempunyai kontribusi yang sangat positif terhadap hasil belajar siswa, seperti yang dikemukakan oleh Jiang (dalam Thalib, 2010), bahwa perkembangan konsep diri dan percaya diri yang positif akan berpengaruh positif terhadap perkembangan sosial. Siswa yang memiliki konsep diri positif menjadi tidak cemas dalam menghadapi situasi baru, mampu bergaul dengan teman-teman seusiannya, lebih koperatif dan mampu mengikuti aturan dan norma-norma yang berlaku. Bahkan siswa yang mempunyai konsep diri positif secara nyata akan mampu mengatasi problem dalam kehidupan keseharian, cenderung lebih independen, percaya diri dan bebas dari karakteristik yang tidak diinginkan seperti kecemasan, kegelisahan, perasaan takut yang berlebihan, dan perasaan kesiapan.

Tumbuh (dalam Dusalan, 2013; 10), mengungkapkan hasil penelitiannya bahwa terdapat kontribusi positif dan signifikan antara perhatian orang tua dengan hasil belajar siswa. lebih lanjut dikatakannya bahwa besar-kecilnya perhatian yang diberikan orang tua terhadap anak yang satu dengan anak yang lain berbeda. Hal ini dengan sendirinya menambah keunikan karakteristik anak sehingga anak-anak dalam kelas makin bervariasi karena perbedaan latar belakang keluarga dalam hal ini kadar perhatian orang tua. Perhatian orang tua dalam kaitanya 
dengan pendidikan meliputi keterlibatan orang tua dalam kegiatan belajar anak baik di rumah maupun di sekolah, keterlibatan orang tua dalam memberikan pembimbingan belajar bagi anak dan juga menyediakan fasilitas belajar, terutama buku-buku pelajaran serta dorongan untuk lebih menggiatkan anak belajar. Dengan adanya perhatian orang tua yang baik, kecenderungan prestasi belajar yang dicapai juga optimal dan dapat berkontribusi positif.

\section{METODE PENELITIAN}

\section{Jenis penelitian}

Penelitian ini termasuk penelitian ex-post facto (bahasa latin "setelah fakta") yang bersifat kausalitas.

\section{Definisi Operasional}

Untuk memperoleh gambaran yang jelas tentang variabel-variabel dalam penelitian ini, maka akan diberikan batasan-batasan sebagai berikut:

\section{Konsep Diri $\left(X_{1}\right)$}

Konsep diri matematika yang dimaksud dalam penelitian ini adalah pandangan seorang individu mengenai kepribadiannya. Adapun indikator konsep diri adalah: (1) konsep diri umum (nilai-nilai/ aturan dan prinsip hidup) dan (2) konsep diri khusus yaitu konsep diri akademik (kemampuan akademik, hasil belajar), konsep diri sosial (hubungan dengan teman sebaya dan keluarga), dan presentasi diri (kepercayaan diri dan penampilan fisik).

\section{Perhatian Orang Tua $\left(X_{2}\right)$}

Perhatian orang tua yang dimaksud pada penelitian ini yaitu persepsi siswa atau anak terhadap perhatian yang diberikan orang tua terhadap anak. Adapun indikator Perhatian orang tua meliputi; (1) mengontrol belajar anak; (2) menciptakan suasana belajar anak; (3) memberikan motivasi belajar anak; (4) membantu memecahkan dan kesulitan belajar anak; (5) menyediakan fasilitas dan perlengkapan belajar anak; (6) mengatur waktu belajar anak; (7) memberikan sanksi atau hukuman; dan (8) memberikan hadiah (reward).

\section{Hasil Belajar (Y)}

Tes hasil belajar (THB) merupakan tes penguasaan, karena tes ini mengukur penguasaan siswa terhadap materi yang diajarkan oleh guru atau dipelajari oleh siswa. Tes 
hasil belajar (THB) diujikan setelah siswa memperoleh sejumlah materi sebelumnya dan pengujian dilakukan untuk mengetahui penguasaan siswa atas materi yang telah dipelajari, Namun dalam penelitian ini tes hasil belajar (THB) yang digunakan untuk mengukur hasil belajar adalah Tes hasil belajar (THB) ranah kognitif siswa kelas X SMA, selama satu semester genap tahun pelajaran 2017/2018.

\section{Populasi dan Sampel}

Populasi dalam penelitian ini adalah seluruh siswa kelas $\mathrm{X}$ pada semua SMA di kecamatan Wera Bima tahun ajaran 2017/2018.. Berdasarkan data yang diperoleh dari kantor Dinas Pendidikan Kabupaten Bima di peroleh jumlah SMA yaitu, Negeri 1 Wera, SMA Negeri 2 Wera, SMAN 3 Wera, SMKN 1 Wera dan SMKN 2 Wera.

Sampel penelitian ini adalah sebagian siswa kelas X SMA di kecamatan Wera tahun pelajaran 2017/2018. teknik pengambilan sampel adalah secara proporsional stratified random sampling, dengan berdasarkan pengelompokan status sekolah yaitu status sekolah non kejuruan sebanyak 3 sekolah, dan status sekolah kejuruan 2 sekolah. Kemudian sekolah yang diambil sebagai sampel penelitian adalah sebanyak 3 sekolah dengan melakukan random, sehingga diperoleh adalah SMA Negeri 1 Wera, SMA Negeri 2 Wera dan SMKN 1 Wera

\section{Teknik Analisis Data}

Teknik analisis yang digunakan adalah statistik deskriptif dan analisis jalur (Path Analysis). Analisis deskriptif diperlukan untuk mendeskripsikan data dari variabel-variabel penelitian yang diajukan. Untuk teknik analisis deskriptif meliputi mean, median, variansi, skewness, kurtosis, minimum, maksimum, dan tabel distribusi frekuensi.

\section{Hasil Analisis Data}

Dari hasil analisis data menunjukkan bahwa rata-rata skor konsep diri siswa adalah 70,00 dari skor ideal 100 yang berarti konsep diri siswa tersebut berada dalam kategori tinggi. Dapat diketahui pula bahwa tidak ada siswa yang mempunyai skor konsep diri yang berada dalam kategori sangat rendah dan kategori rendah, 98 orang yang berada dalam kategori sedang, 101 orang yang berada dalam kategori tinggi, dan tidak ada siswa yang mempunyai skor dalam kategori sangat tinggi.

Untuk variabel perhatian orang tua siswa adalah rata-rata 72,60 dari skor ideal 120 yang berarti perhatian orang tua siswa tersebut berada dalam kategori sedang. Dapat diketahui 
pula bahwa 4 orang siswa yang mempunyai skor perhatian orang tua yang berada dalam kategori sangat rendah, sedangkan 47 orang yang berada dalam kategori rendah, 100 orang yang berada dalam kategori sedang, 46 orang yang berada dalam kategori tinggi dan 2 orang lainnya berada dalam kategori sangat tinggi. Sedangkan untuk Hasil belajar matematika menunjukkan bahwa skor rata-rata adalah 65,83 dari skor ideal 100 yang berarti hasil belajar matematika siswa tersebut berada dalam kategori tinggi. dapat diketahui pula bahwa tidak ada siswa yang mempunyai skor hasil belajar matematika yang berada dalam kategori sangat rendah, sedangkan 12 siswa yang berada dalam kategori rendah, 61 siswa yang berada dalam kategori sedang, 115 siswa yang berada dalam kategori tinggi dan 11 siswa yang berada dalam kategori sangat tinggi

\section{HASIL DAN PEMBAHASAN}

\section{Faktor Psikologis Konsep Diri, dan Perhatian Orang Tua Secara Bersama-Sama (Simultan) berkontribusi terhadap Hasil Belajar Matematika.}

Berdasarkan hasil penelitian bahwa konsep diri, dan perhatian orang tua secara bersama-sama (simultan) berkonstribusi terhadap hasil belajar matematika. Selanjutnya dapat dijelaskan hasil pengujian dengan menggunakan software komputer Statistic Package Sosial Science (SPSS) for windows 20, maka dapat diketahui bahwa hipotesis pertama diterima dengan analisis variansi (uji F) diperoleh nilai $F_{\text {hitung }} 8,107$ dengan nilai probabilitas $<0,001$ artinya jauh lebih kecil dari nilai $\alpha=0,05$.

Angka diatas menjelaskan bahwa hubungan konsep diri, dan perhatian orang tua secara bersama-sama (simultan) berpengaruh secara signifikan terhadap hasil belajar matematika. Dimana persamaan garis regresinya yaitu $\bar{Y}=\rho_{\mathrm{YX} 1} \mathrm{X} 1+\rho_{\mathrm{YX} 2} \mathrm{X} 2+\rho_{\mathrm{Y}} \varepsilon_{1}$ atau $\overline{\mathrm{Y}}=0,049 \mathrm{X} 1+$ $0,005 \mathrm{X} 2+0,889 \varepsilon_{1}$. Lebih lanjut bahwa kontribusi konsep diri, dan perhatian orang tua secara bersama-sama (simultan) terhadap hasil belajar matematika siswa SMA kelas X (sepuluh) di

kecamatan Wera Bima, sebesar sebesar $\mathrm{R}_{\text {square }}^{2}=0,111$ atau 11,10\%. Sementara sisanya sebesar 0,889 atau 88,90\% dipengaruhi faktor-faktor lain yang tidak dapat dijelaskan dalam penelitian ini. 
JFaktor Psikologis Konsep Diri berkontribusi positif Terhadap Hasil Belajar Matematika.

Berdasarkan hipotesis yang kedua bahwa konsep diri berkontribusi positif terhadap hasil belajar matematika. Selanjutnya dapat dijelaskan hasil pengujian dengan menggunakan software komputer Statistic Package Sosial Science (SPSS) for windows 20, maka dapat diketahui bahwa konsep diri berkontribusi positif terhadap hasil belajar matematika dengan nilai koefisien jalur sebesar 0,157 atau sebesar $15,70 \%$, sementara sisanya sebesar 0,843 atau $84,30 \%$, dipengaruhi faktor-faktor lain yang tidak dapat dijelaskan dalam penelitian ini.

\section{Faktor Psikologis Perhatian Orang Tua Berkontribusi Positif Terhadap Hasil Belajar Matematika}

Berdasarkan hipotesis yang ketiga bahwa perhatian orang tua berkontribusi positif terhadap hasil belajar matematika. Berdasarkan hasil pengujian dengan menggunakan software komputer Statistic Package Sosial Science (SPSS) for windows 20 maka dapat diketahui bahwa perhatian orang tua berkontribusi positif terhadap hasil belajar matematika dengan nilai koefisien jalur sebesar 0,198 atau sebesar 19,80\%, sementara sisanya sebesar 0,802 atau $80,20 \%$, dipengaruhi faktor-faktor lain yang tidak dapat dijelaskan dalam penelitian ini

\section{KESIMPULAN}

Berdasarkan hasil analisis data penelitian pada bab IV sebelumnya, beberapa kesimpulan dari hasil penelitian ini adalah: (1) Kontribusi positif konsep diri, dan Perhatian orang tua secara bersama-sama (simultan) terhadap hasil belajar matematika siswa kelas $\mathrm{X}$ SMA di Kecamatan Wera Kabupaten Bima, sebesar 11,10\%; (2) Kontribusi positif konsep diri terhadap hasil belajar matematika siswa kelas X SMA di Kecamatan Wera Kabupaten Bima, sebesar 15,70\%; (3) Kontribusi positif perhatian orang tua terhadap hasil belajar matematika siswa kelas X SMA di Kecamatan Wera Kabupaten Bima, sebesar 19,80\%;

\section{REKOMENDASI}

Adapun rekomendasi yang perlu disampaikan bahwa: (1) Faktor yang mempengaruhi hasil belajar matematika siswa dalam penelitian ini meliput konsep diri berada dalam kategori tinggi, perhatian orang tua berada dalam kategori sedang, dan termasuk hasil belajar matematika berada dalam kategori tinggi. Oleh karena itu dapat diberikan saran untuk para guru, orang tua, dan para pengambil kebijakan agar mempertahankan hasil belajar yang dicapai dan dapat meningkatkan prestasi yang lebih 
baik lagi; (2) Konsep diri, dan perhatian orang tua, berkontribusi positif terhadap hasil belajar matematika siswa. Oleh karena itu para guru, orang tua, dan para pengambil kebijakan ataupun lembaga-lembaga lainnya diharapkan dapat mendorong siswa/siswi agar dapat meningkatkan untuk meraih prestasi belajar matematika siswa.

\section{UCAPAN TERIMAKASIH}

Pada kegiatan penelitian ini, saya menyampaikan ucapan terima kasih yang tak terhingga kepada yang terhormat ketua STKIP Bima Bapak DR. H. Amran Amir, M.Pd, dan Bapak Ketua Program Studi Pendidikan Matematika Bapak Edi Mulyadin, S.Pd.,M.Pd, yang mendorong saya untuk selalu meluangkan waktu untuk menulis, selanjutnya saya menyampaikan ucapan terima kasih pula kepada yang terhormat bapak/Ibu Kepala Sekolah SMA Se-Kecamatan Wera yaitu ibu Dra. Rohani, ibu Dra. Raodah dan Bapak Gufran, S.Pd. tidak lupa pula saya menyampaikan ucapan terima kasih kepada istri dan anak saya yaitu Nurhidayah, Amd.Keb dan Tristan Kholief MD yang selalu mendorong untuk berkarier.

\section{REFERENSI}

Agustin, M. (2011). Permasalahan Belajar dan Inovasi Pembelajaran. Bandung: PT Refika Aditama.

Ahmad, J. Ghazali, M. \& Hassan, A. (2011). Hubungan Antara Konsep Diri dan Tanggapan Menuju Prestasi Akademik Siswa Antara Mahasiswa di Universitas Putra Malaysia (Vol. 4 No. 2 Juli 2011). Jurnal (diterbitkan terjemahan). Selangor: Universitas Putra Malaysia.

Ali, R. Akhter, A. Shahzad, S. Sultan, N. \& Ramzan, M. (2011). Dampak Motivasi Terhadap Prestasi Akademik Dalam pembelajaran Matematika Dalam Masalah Berbasis Lingkungan (Vol.3 No.1 Januari 2011). Jurnal (diterbitkan terjemahan). Pakistan: Universitas Internasional Korakrum.

Apriyati, T., Joharman, \& Budi, H. S. (2011). Pengaruh Perhatian Orang Tua dan Minat Membaca Terhadap Hasil Belajar Bahasa Indonesia (Jurnal diterbitkan FKIP universitas sebelas maret Surakarta, diakses 10 Oktober 2018).

Awan, NR, Noureen, G \& Naz, A. (2011). Sebuah Studi Hubungan Antara Motivasi Berprestasi, Self Konsep dan Prestasi dalam Bahasa inggris dan Matematika pada 
Tingkat Menengah (Vol.4 No.3 Agustus 2011). Jurnal (diterbitkan terjemahan). Pakistan: Universitas Sargodha

Dusalan. (2013). Kontribusi Konsep diri, dan perhatian orang tua terhadap hasil belajar matematika melalui motivasi berprestasi pada siswa SMA Se-kecamatan Wera (Vol. 1 No.1 Maret 2017).

Ilhamsyah. (2012). Pengaruh efikasi diri, metakognisi dan regulasi diri terhadap prestasi belajar matematika Siswa Kelas X SMA Negeri di Kabupaten Wajo (Tesis PPs UNM tidak diterbitkan)

Maria, U. (2012). Kontribusi Konsep Diri dan Motivasi Berprestasi Terhadap Hasil Belajar Biologi Siswa SMA di Makassar. (Tesis PPs UNM tidak diterbitkan)

Maria, U. (2012). Peran Persepsi Keharmonisan Keluarga dan Konsep Diri Terhadap Kecenderungan Kenakalan Remaja (Tesis PPs UGM di akses tanggal 10 Oktober 2018)

Rasyid. H \& Mansyur. (tt). Penilaian Hasil Belajar. Bandung: CV Wacana

Riduwan . (2012). Belajar Mudah Penelitian. Bandung: Alfabeta

Riduwan \& Kuncoro, E. A., (2012). Path analysis. Bandung: Alfabeta

Pencapaian Akademik Siswa, Serta Upaya Pembentukan Konsep Diri Berbasis Aktifitas Pembelajaran. (diterbitkan) (http//www. Myblog tesis kesari. com, diakses pada tanggal 10 Oktober 2018)

Sudjana, N. (2011). Penilaian Hasil Proses Belajar Mengajar. Bandung: PT Remaja Rosdakarya

Sugiyono. (2011). Metode Penelitian Kuantitatif Kualitatif dan R \& D. Bandung: Alfabeta

Sutrisnawati, N. N. (2012). Kontribusi Perhatian Orang Tua, Kebiasaan Belajar dan Kemampuan Guru dalam Mengelola Proses Pembelajaran Terhadap Prestasi Belajar Siswa pada Bidang Studi yang di-UAN-kan (Studi Persepsi siswa kelas XII SMAN 1 BLAHBATUH).

Triyani, U. (2012). Kontribusi Konsep Diri dan Motivasi Berprestasi Terhadap Hasil Belajar Biologi Siswa SMA di Makassar. (Tesis PPs UNM tidak diterbitkan)

Uno, B. H. (2011). Teori Motivasi dan Pengukurannya. Jakarta: Bumi Aksara. 